\title{
Little Akaki River sediment enrichment with heavy metals, pollution load and potential ecological risks in downstream, Central Ethiopia
}

Deshu Mamo Mekuria', Alemnew Berhanu Kassegne ${ }^{2}$ and Seyoum Leta Asfaw ${ }^{1 *}$ (1)

\begin{abstract}
Addis Ababa City's river ecosystem is under extreme pressure as a result of inappropriate practices of dumping domestic and industrial wastes; thus, threatening its ability to maintain basic ecological, social and economic functions. Little Akaki River which drains through Addis Ababa City receives inorganic and organic pollutants from various anthropogenic sources. Most of inorganic pollutants such as toxic heavy metals released into the river are eventually adsorbed and settle in the sediment. The objective of this study was to evaluate the enrichment levels, pollution load and ecological risks of selected heavy metals ( $\mathrm{Zn}, \mathrm{Cr}, \mathrm{Cd}$ and $\mathrm{Pb})$ using various indices. The mean concentrations of heavy metals in Little Akaki River sediment were: Zn $(78.96 \pm 0.021-235.2 \pm 0.001 \mathrm{mg} / \mathrm{kg}) ; \mathrm{Cr}$ $(2.19 \pm 0.014-440.8 \pm 0.003 \mathrm{mg} / \mathrm{kg}) ; \mathrm{Cd}(2.09 \pm 0.001-4.16 \pm 0.0001 \mathrm{mg} / \mathrm{kg})$ and $\mathrm{Pb}(30.92 \pm 0.018-596.4 \pm 0.066 \mathrm{mg} /$ $\mathrm{kg}$ ). Enrichment factor values indicated that sediments were moderate to significantly enriched with $\mathrm{Zn}$ and $\mathrm{Cr}$; moderate to very highly enriched with $\mathrm{Pb}$, and very highly enriched in all sampled sites with $\mathrm{Cd}$. Geo-accumulation index and contamination factor values indicated that the sediments were moderate to very highly contaminated with toxic $\mathrm{Cd}$ and $\mathrm{Pb}$. The decreasing order of pollution load index (PLI) in downstream was: $(\mathrm{S} 9)>(\mathrm{S} 4)>(\mathrm{S} 8)>(\mathrm{S} 3)>(\mathrm{S} 6)>$ $(\mathrm{S} 10)>(\mathrm{S} 5)>(\mathrm{S} 2)>(\mathrm{S} 7)>(\mathrm{S} 1)$. PLI and hierarchical cluster analysis revealed that the highest pollution load occurred in the lower course of the river (S9) which may be due to metals inputs from anthropogenic sources. The ecological risk $(R I=350.62)$ suggested that the contaminated Little Akaki River sediment can pose considerable ecological risks of pollution. The concentrations of $\mathrm{Zn}, \mathrm{Cr}, \mathrm{Cd}$ and $\mathrm{Pb}$ in Little Akaki River sediment surpassed eco-toxicological guideline limits of USEPA (threshold effect concentration) and CCME (Interim Sediment Quality Guidelines). Thus, the contaminated sediments can pose adverse biological effects on sediment dwelling organisms.
\end{abstract}

Keywords: Enrichment factor, Ecological risks index, Geo-accumulation index, Pollution load

\section{Background}

Heavy metals released from industries, municipal waste treatment plant sites, domestic and garages into surrounding surface water bodies impair the quality of water and sediment. In surface water, trace metals are carried away by water in suspended form and eventually deposited in sediment through the process of precipitation,

\footnotetext{
*Correspondence: seyoum.leta@aau.edu.et

${ }^{1}$ Center for Environmental Science, Addis Ababa University, P.O. Box 1176, Addis Ababa, Ethiopia

Full list of author information is available at the end of the article
}

co-precipitation, adsorption and chelation (Rabee et al. 2011; Singovszka and Balintova 2016). However, the metal retention capacity of sediment is subjected to many environmental factors such as natural and anthropogenic disturbances of the river water and sediment, change in water $\mathrm{pH}$ and redox potential (Akan et al. 2010; Edokpayi et al. 2016). When a change in environmental factors occur, sediment-bound metals are released into overlaying water through the process of dissolution of metals, decomposition of organic matters and desorption (Zhu et al. 2017), and causing the secondary source pollution to river water (Luo et al. 2010; Ren et al. 2015). 
Sediment pollution with heavy metals has become an important local, national and global problem that affects water quality, aquatic life and results in far-reaching environmental and public health problems. This is mainly attributed to the properties of heavy metals which include: persistence in the environment, bioaccumulation, and bio-magnification along the food chain. Some of the trace metals like $\mathrm{Cd}$ and $\mathrm{Pb}$ are non-essential elements to plants and animals which can cause various health repercussions. Therefore, assessing and determining the levels of sediment contamination with toxic trace metals, ecological risks and eco-toxicological adverse effects of heavy metals are necessary for environmental monitoring and design of mitigation measures.

Little Akaki River (LAR) drains through Addis Ababa City and peri-urban areas where several industries have been established, a large number of city populations have been residing, and where small scale farmers use agrochemicals for vegetable cultivation along the river banks. It receives poorly treated and untreated industrial, domestic and agricultural wastes (Melaku 2005) that carry heavy metals to the river sediment.

Previous studies on Little Akaki River sediments were limited to the assessment of the concentrations and distribution of some selected heavy metals (Gizaw 2018; Melaku 2005; Nigussie et al. 2013; Tolla 2006), and their distribution and ecological risk in the sediments of Akaki catchment areas (Berhanu et al. 2018). There is, however, information gap on the levels of Little Akaki River sediment contamination and the source of trace metal elements. Moreover, no conclusive data exist on the potential ecological risks and eco-toxicological implications of toxic metals accumulation in sediments.

Therefore, the objectives of the study were: (i) to determine the level of selected heavy metals $(\mathrm{Zn}, \mathrm{Cr}, \mathrm{Cd}$ and $\mathrm{Pb}$ ) in Little Akaki River sediment; (ii) to evaluate sediment contamination using various quality indices, and (iii) to assess the potential ecological and eco-toxicological risk of sediment pollution and its implications for aquatic life and river ecosystem.

\section{Materials and methods}

\section{Description of the study area}

The study was conducted on Little Akaki River sediment which is found in Akaki Catchment, Central Ethiopia. The river starts from Geferssa Reservoir which is located at foot of Entoto Mountain and drains through Addis Ababa City, the capital city of Ethiopia, and finally joins Aba-Samuel Reservoir (Fig. 1). The City is located at $9^{\circ} 2^{\prime} \mathrm{N}$ and $38^{\circ} 42^{\prime} \mathrm{E}$. Little Akaki River flows through varied altitudes that range from $2464 \mathrm{~m}$ above sea level (m.a.s.l.) at around Geferssa Reservoir in the north to 2048 m.a.s.l. at the merge to Aba-Samuel Reservoir in the

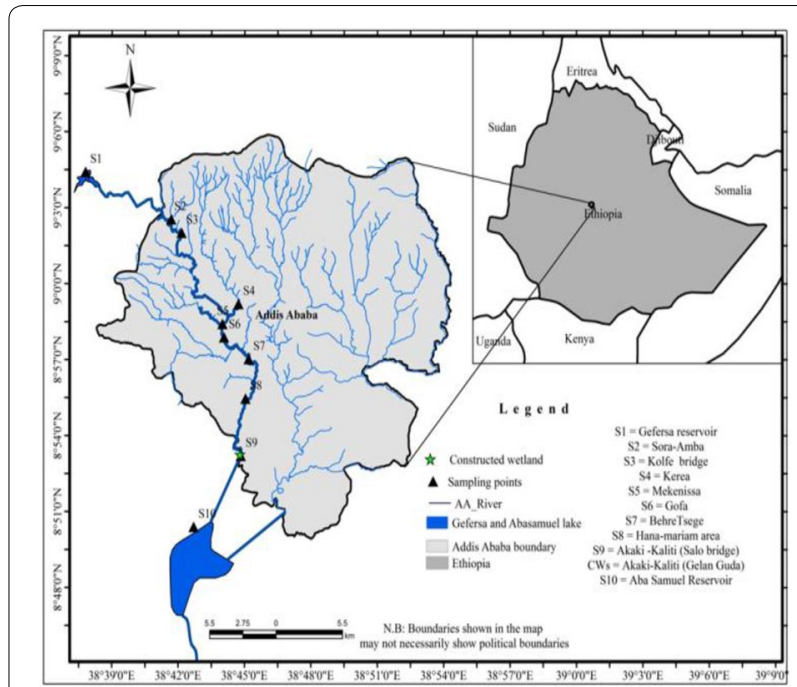

Fig.1 Map of the study area

south. The river drains a total catchment area of about $540 \mathrm{~km}^{2}$ (Nigussie et al. 2013). In the upper catchment, the river flows through a deep gorge, on a rocky bed with turbulences whereas in the lower catchment, it flows in a gentle slope landscape that is surrounded by irrigated vegetable farms and grazing lands. There are 2 types of soil predominantly found around Little Akaki River: vertisol which is commonly found on top of gentle slope lands and fluvisol at bottom of slope lands and on adjacent to the Akaki River banks (Itanna et al. 2003).

Little Akaki River is one of the major rivers crossing through the city and largely used for socio-economic development activities. Urban and peri-urban farmers downstream are using this river water laden with pollutants for the cultivation of vegetables around the river banks and supply the City with fresh vegetables. Moreover, peri-urban communities and farmers are largely dependant on the river water for cattle drinking, washing, recreational and even for domestic uses as well as sand mining during the dry season. Fishing is also undertaken in the lower parts of the river course and the AbaSamuel Reservoir.

\section{Sampling sites and sample collection}

Ten sampling sites were selected along Little Akaki River based on its accessibility and proximity to point sources (industrial and municipal waste discharge points) and non-point sources (irrigated farms), permanently identifiable physical features. Accordingly, the selected sampling sites and their locations include: upstream at Geferssa Reservoir (S1-control sample); Soramba, just after the merge of Burayu and Wingate stream (S2); Kolfe bridge (S3); below Kera bridge in proximity to Addis 
Ababa City abattoir (S4); below Mekenissa bridge where clusters of small scale vegetable farming are found (S5); below Gofa bridge (S6); Bihire-Tsige vegetable farm area (S7); in proximity to Akaki Kalti industrial area (S8); below Gelan Guda Kebele bridge at the middle of irrigated farmland (S9); and Aba Samuel Reservoir at the merge of Little Akaki River and the reservoir (S10) (Fig. 1). The exact geographical location and altitude of each sampling site were recorded using GPS (GARMIN, GPSMAP62st).

Composite sediment samples were collected from these selected sites in April 2018 between 9:00-11:00 AM, during the dry season when river flow was minimal following the procedures described in USEPA (2001). At each sampling site, three grab sediment samples of nearly the same amount were randomly collected using a clean plastic scoop (grasp sampling technique) from the depth of 0-10 cm, starting from most downstream samples along the straight section of the river with the least disturbance. The grab samples were thoroughly mixed to form homogenized composite sediment samples. At each site, the physical status of the sediment was noted based on OhioEPA (2001). The sediment samples of 1500-2000 gm per site were placed in dense polyethylene bags, sealed, labeled and immediately transported to the Center for Environmental Science laboratory, Addis Ababa University and the sediment samples were kept in the refrigerator at $4{ }^{\circ} \mathrm{C}$ until they were further processed.

\section{Determination of $\mathrm{pH}$ and particle size composition}

Following the procedures described in Mohiuddin et al. (2010), the sediment and water were mixed at a ratio of $1: 2.5$, thoroughly stirred for $30 \mathrm{~min}$. and the suspension was allowed to stay overnight. The sediment sample $\mathrm{pH}$ was measured using $\mathrm{pH}$ Meter (model: PHS-3CB ACC-Deg-0.01). The particle size compositions of the sediments were determined following the procedures described in Özkan (2012). The sediment particle size distribution was grouped into four texture classes based on the sieve result as clay $<0.002 \mathrm{~mm}$; silt $=0.002-$ $0.063 \mathrm{~mm}$; sand $=0.063-2 \mathrm{~mm}$; and gravel $>2 \mathrm{~mm}(\mathrm{Hu}$ et al. 2013). Each sieve result was carefully collected and weighted using an electronic balance (Model: JD210-4 CE). The percent of grain size (\%) was computed using the formula described in Uwah et al. (2013), which is expressed as \% grain size $=$ (Sieve weight/ total weight) $\times 100$. The sediment composition/texture/ classes were determined based on the ternary diagram of flok's classification.

\section{Pretreatment and digestion of sediment samples for heavy} metal analysis

Unwanted materials such as leaves, debris, shells and coarse gravels were carefully removed and the sediment samples were air-dried at ambient room temperature until a constant weight was obtained. The dried sediment samples were powdered using mortar and pestle and sieved using $45 \mu \mathrm{m}$ sieve. Following the procedures described in Sekabira et al. (2010), $1.25 \mathrm{~g}$ of the subsample of sediment was taken from each sample and digested with $20 \mathrm{~mL}$ aqua regia $\left(3: 1 \mathrm{HCl} / \mathrm{HNO}_{3}\right)$ and then, with $5 \mathrm{~mL} \mathrm{H}_{2} \mathrm{O}_{2}$ in an open beaker using heat plate until the digest reaches near dryness. The beaker was rinsed with $10 \mathrm{~mL}$ of de-ionized water and the samples were further digested with $5 \mathrm{~mL} \mathrm{HCl}$ to near dryness. Finally, the digest was cooled and the beaker was rinsed with $50 \mathrm{~mL}$ de-ionized water and was transferred into a small flask. The concentration of heavy metals $(\mathrm{Cd}, \mathrm{Cr}, \mathrm{Pb}$ and $\mathrm{Zn})$ in the sediment samples was determined using inductively coupled plasma optical emission spectrometry (ICP-OES Arcos Spectrophotometer, made in Germany).

\section{ICP-OES operating conditions and calibration} of the instrument

All the measuring conditions were configured as follows: plasma power $(1400 \mathrm{~W})$, average plasma flow rate $(6.41 \mathrm{~L} / \mathrm{min}$.), pumping speed $(30 \mathrm{rpm})$, nebulizer flow (0.73 L/min.), nebulizer pressure (1.96 bar), Argon pressure (6.75 bar), and torch positions and measuring time adjusted. The calibration and standardization of the spectra method were performed according to the standard protocols set for the instrument. But, standardization is undertaken daily: it is a quick procedure for correcting measuring intensities so that the correct concentrations of the element is obtained using the calibration curve. Calibration curves were prepared using $0.06,0.11,0.17,0.56,1.12,1.68,2.24$ and $2.80 \mathrm{mg} / \mathrm{L}$ of $\mathrm{Zn} ; 0.03,0.06,0.08,0.28,0.56,0.84,1.12$, and $1.40 \mathrm{mg} / \mathrm{L}$ of $\mathrm{Cr}, \mathrm{Cd}$ and $\mathrm{Pb}$. Quantifications of the elements were recorded at 213.856, 231.604, 267.716 and $220.353 \mathrm{~nm}$, which correspond to the most sensitive emission wavelengths of $\mathrm{Zn}, \mathrm{Cd}, \mathrm{Cr}$ and $\mathrm{Pb}$, respectively. The sample was nebulized and the concentration was calculated on the linear graph of the standard concentration and the corresponding intensities. The calibration curve showed linearity, $\mathrm{R}^{2}$ of 0.999964 for $\mathrm{Cd}, 0.999874$ for $\mathrm{Cr}, 0.999757$ for $\mathrm{Pb}$ and 0.999439 for $\mathrm{Zn}$. Thus, there is a good correlation between concentration and emission intensities of the analyzed elements. 


\section{Assessment of levels of sediment contamination}

The levels of Little Akaki River sediment contamination with heavy metals were assessed using indices such as enrichment factor (EF), geo-accumulation $\left(\mathrm{I}_{\text {geo }}\right)$, contamination factor (CF), pollution load index (PLI), potential ecological risks index (PERI) and risk index (RI).

\section{Enrichment factor (EF)}

The EF is often used to assess natural and anthropogenic sources of trace metals and the status of sediment contaminations (Zhao et al. 2017). EF was determined using the formula described in Issa and Qanba (2016) which is expressed as:

$$
\text { Enrichment factor }=\frac{(\mathrm{Cx} / \mathrm{Fe}) \text { samples }}{\left(\frac{\mathrm{Cx}}{\mathrm{Fe}}\right) \text { backgroundvalue }}
$$

where " $\mathrm{C}_{\mathrm{x}}$ " stands for concentration of metal in sediment sample, and "Fe" concentration of iron in a given sediment sample. The element "Fe" was taken as a normalizing element, because, its abundance in the earth's crust has not been much influenced by anthropogenic activities (Al Obaidy et al. 2014). For geochemical background value, the world average shale values for elements were adopted from Turekian and Wedepohl (1961). According to Issa and Qanba(2016), the resulting EF value can be categorized into five classes. These are (i) class 1: deficiency to minimal level of enrichment $(\mathrm{EF}<2)$; (ii) class 2: moderate enrichment $(2 \leq \mathrm{EF}<5)$; (iii) class 3 : significant enrichment $(5 \leq \mathrm{EF}<20)$; (iv) class 4 : very high enrichment $(20 \leq \mathrm{EF}<40)$; and (v) class 5 : extremely high enrichment $(E F \geq 40)$.

\section{Geo-accumulation index ( $\left.I_{\text {geo }}\right)$.}

This index was used to evaluate the magnitude of sediment contamination as described in Rubio et al. (2000). Geo-accumulation index was calculated (Banu et al.2013) as follows:

$$
I_{\text {geo }}=\log _{2}\left[C_{n} / 1.5 B_{n}\right]
$$

where " $C_{n}$ " represents the concentration of heavy metal in sample sediment, " $\mathrm{B}_{\mathrm{n}}$ " stands for the world average shale value of metal element "n", while factor 1.5 was applied for correction of background matrix attributed to lithogenic variations (Ke et al. 2017).

According to Muller (1981), the computed $\mathrm{I}_{\text {geo }}$ value can be categorized in to seven classes showing level of pollution as follows: class 0: unpolluted ( $\mathrm{I}_{\text {geo }}$ value $\leq 0)$; class 1 : unpolluted to moderately polluted $\left(\mathrm{I}_{\text {geo }}\right.$ value $\left.=0-1\right)$; class 2 : moderately polluted ( $\mathrm{I}_{\text {geo }}$ value $=1-2$ ); class 3 : moderately to strongly polluted ( $\mathrm{I}_{\text {geo }}$ value $=2-3)$; class 4 : strongly polluted $\left(\mathrm{I}_{\text {geo }}\right.$ value $\left.=3-4\right)$; class 5: strongly to extremely polluted $\left(\mathrm{I}_{\text {geo }}\right.$ value $\left.=4-5\right)$; class 6: extremely polluted $\left(\mathrm{I}_{\text {geo }}\right.$ value $\left.>6\right)$.

\section{Contamination factor (CF)}

Contamination factor is commonly used to demonstrate the level of contamination of sediment by particular toxic metal at a given sample size (Manoj and Padhy 2014). It is defined as:

$$
\mathrm{CF}=\frac{\text { Cmsample }}{\text { Cmbackground }}
$$

where " $C_{m}$ sample" stands for metal concentration in sample sediment; " $\mathrm{C}_{\mathrm{m}}$ background" is the geochemical background value of the metal.

According to Hakanson (1980), the CF can be categorized as follows: (i) class 1: low level of sediment contamination $(\mathrm{CF}$ value $<1$ ); (ii) calss 2 : moderate contamination $(1 \leq \mathrm{CF}$ value $<3)$; (iii) class 3 : considerable contamination ( $3 \leq \mathrm{CF}$ value $<6$ ); (iv) class 4 : very high contamination (CF value $>6$ ).

\section{Pollution load index (PLI)}

Pollution load index is an important index to compare the pollution status of different sampling sites downstream ( Rabee et al. 2011). The pollution load index of Little Akaki River was determined using the formula described in Rabee et al. (2011) and Tomilson et al. (1980) which is expressed as:

$$
\mathrm{PLI}=\left(\mathrm{CF}_{1} \times \mathrm{CF}_{2} \times \mathrm{CF}_{3} \mathrm{x} \times \mathrm{xF}_{\mathrm{n}}\right)^{1 / \mathrm{n}}
$$

where " $\mathrm{CF}_{1}, \mathrm{CF}_{2}, \mathrm{CFn}$ ", stands for the contamination factor of each element, " $n$ " = the number of metals under study. According to Tomilson et al. (1980) sediment is considered to be polluted,if PLI value $>1$; otherwise, not polluted for PLI value $<1$.

\section{Potential ecological risk index (PERI) and risk index (RI)}

PERI and RI were used to assess an overall potential ecological risk of heavy metals in sediment, pollution status and eco-toxicological aspect (Hakanson 1980; Ke et al. 2017). To compute PERI and RI, toxicity response factor (TRF) value for $\mathrm{Pb}=5 ; \mathrm{Cd}=30 ; \mathrm{Cr}=2$, and $\mathrm{Zn}=1$ were adopted from Banu et al. (2013); Li (2014).

$$
\text { PERI of the metal element }\left(E_{r}^{i}\right)=T_{r}^{i} \mathbf{x}(C i / C o)
$$

$$
\operatorname{Risk} \operatorname{Index}(\mathrm{RI})=\sum_{i=1}\left(\begin{array}{l}
E_{r}^{i} \\
r
\end{array}\right)
$$

where " $C_{i}$ " stands for the concentration of metal in sample sediment, " $\mathrm{C}_{\mathrm{o}}$ " represents background concentration, 
“ $\mathrm{T}_{\mathrm{r}}^{\mathrm{i}}$ " toxicity response factor of single element, " $\mathrm{E}_{\mathrm{r}}^{\mathrm{i}}$ " potential ecological risk of each metal element under the study.

According to Hakanson (1980), the PERI value indicating the severity of the ecological risk of sediment pollution can be grouped into five classes. Class 1: low pollution risk (PERI value $<40$ ); class 2 : moderate risk (PERI value between 40-80); class 3: considerable risk (PERI value between 80-160); class 4: high risk (PERI value between 160-320); and class 5: very high risk of pollution (PERI value $>320$ ). Similarly, the computed value of RI is categorized into four classes as follows: class 1 : low risk (RI value $<150)$; class 2 : moderate risk (RI value between 150-300); class 3: considerable risk (RI value between 300-600), and class 4: high risk (RI value $>600$ ).

\section{Assessment of eco-toxicological effects}

To evaluate toxicological adverse effects of contaminated sediments on aquatic life and ecosystem, the concentration of heavy metals in the sediments were assessed in relation to threshold effect concentration (TEC) and probable effect level (PEL) concentration of USEPA (2002), and interim sediment quality guidelines (ISQG) and PEC of Canadian Council of Ministers of the Environment (CCME) (2001).

\section{Quality control and quality assurance}

To ensure the quality of heavy metals analysis, the sediment samples were analyzed in triplicate. Blank analyses were carried out to check interference from the laboratory reagents. Blank and spiked samples were prepared to ascertain laboratory performance. The recovery rates of the four metals were: $96.25-105.59 \%$ for $\mathrm{Zn}$; 89.38-112.86\% for $\mathrm{Cr}$; $97.93-116.43 \%$ for $\mathrm{Cd}$, and $99.74-$ $108.75 \%$ for $\mathrm{Pb}$. All of the chemical reagents used for the test were of analytical grade (supplied by Loba ChemieLaboratory Reagents and Fine Chemicals, Laboratory use only) and laboratory-grade Argon gas of 99.996\% was applied. All the glassware used for the test was thoroughly washed, soaked in $10 \% \mathrm{HNO}_{3}$ and rinsing with de-ionized water.

\section{Statistical analysis}

Descriptive statistical analysis was used to determine the concentrations of metals, EF, Igeo, CF, PLI and PERI, and the results were presented in tables and graphs using Microsoft Excel 2010. Pearson correlation and multivariate (hierarchical cluster analysis (HCA) were applied to evaluate sources of metal elements and to group sample sites that were exhibiting similar pollution profiles in downstream. Hierarchical cluster analysis is an important statistical tool widely employed to classify sample sites located in downstream based on the similarity between data set ( Rizvi et al. 2016); hence, grouping sites which have similar data objects into the same cluster, whereas dissimilar data set in other clusters. The cluster analysis was undertaken using R-software (Version 3.3.2). Pearson correlation was determined using SPSS software,Version 20.

\section{Results and discussion}

$\mathrm{PH}$ and particle composition of Little Akaki River sediment The accumulation of heavy metals in sediment can be influenced by sediment $\mathrm{pH}$ and particle size composition (OhioEPA, 2001). The $\mathrm{pH}$ of Little Akaki River sediment samples ranged from 6.04 to 8.19 with a mean value of $7.56 \pm 0.70$. The lowest $\mathrm{pH}$ value (6.04) occurred at the sample site (S1) which showed slightly acidic sediment which may be due to the decomposition of organic matters such as grass and plant derived debris and form humic-acid (Chatterjee et al. 2007). The highest value of $\mathrm{pH}(\mathrm{pH}=8.19)$ was recorded for the sample site (S8) indicating slight alkalinity (Fig. 2). This may be attributed mainly to the deposition of salt and alkaline materials in sediment that is released from point sources such as painting, textile, tanneries and alcohol factories (WWAP 2017) operating in proximity to the river.

The textural compositions of Little Akaki River sediment were grouped into three categories: clay, sandclay-loam and sandy-loam (Table 1; and Fig. 3 ). The clay texture dominated sediment with a certain portion of sand and silt was recorded at sample sites: (S1), which are located in the upper and (S9) and (S10) in the lower parts of the river course. Flat landscape and relatively slow river flow conditions in the most upper and lower courses of the river might have facilitated the deposition of clay particles from the surrounding farmlands.

Sandy-clay-loam textured sediment composition detected at sample site (S3); while sandy-loam texture sediment composition occurred at sample sites: (S4), (S5), (S6) and (S7). These sites were located in the middle

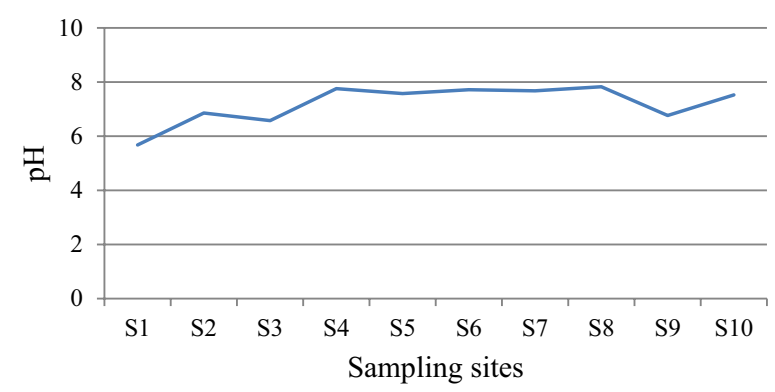

Fig. 2 The $\mathrm{pH}$ of Little Akaki River sediment 
Table 1 Little Akaki River sediment texture class and physical status of the sediment

\begin{tabular}{lll}
\hline Sample sites & Textural class of sediment & Physical status of sediment* \\
\hline S1 & Clay & Plastic and cohesive; sediment contains un-decomposed leaves and plant debris \\
S2 & ND & \\
S3 & Sandy-clay-loam & Sandy; muck (black, consist of completely mineralized organic materials) \\
S4 & Sandy-loam & Sandy; muck (black, consist of completely mineralized organic materials); has the odor \\
S5 & Sandy-loam & Sandy; muck (black, consist of completely mineralized organic materials), \\
S6 & Sandy-loam & Sandy; peat (partially decomposed plant materials) sometimes soil warm visible \\
S7 & Sandy-loam & Sandy; debris (dead and unconsolidated organic materials, and partially decayed coarse plant \\
S8 & ND & \\
S9 & Clay & Muck (black, extremely fine, completely decomposed organic materials); cohesive; has the odor \\
S10 & Clay & Muck (black, extremely fine, completely decomposed organic materials); cohesive; has the odor
\end{tabular}

*Physical status of sediment described based on field observation notes as indicated in OhioEPA (2001). ND No Data (Data not available)

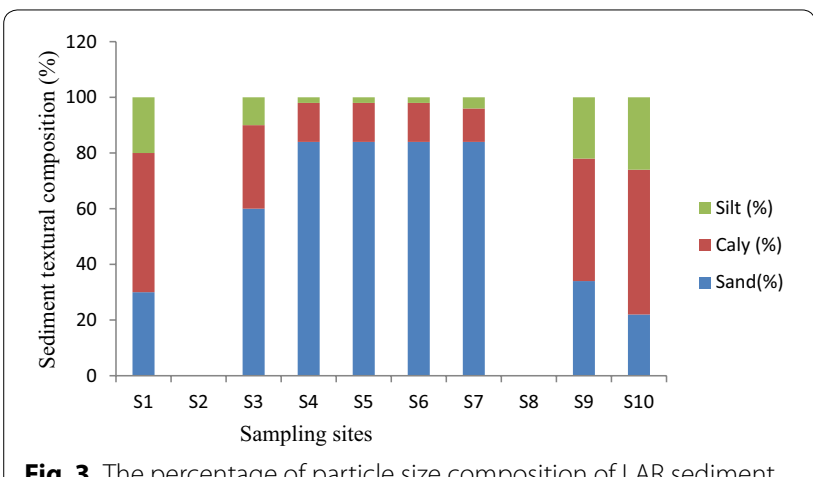

Fig. 3 The percentage of particle size composition of LAR sediment

course of the river which is typically characterized by the rocky river bed, turbulent and fast-moving river water with high materials transporting capacity. Thus, sand dominated sediment texture exhibits the effects of hydrology (Zhao et al. 2017) and the geological condition of the sample sites. In these regards, Chatterjee et al. (2007) and Rubio et al. (2000) have described that varying mixture of sand, silt and clay fractions in the sediment is a result of eroding and materials transport capacity of river water.

\section{Concentration of heavy metals in Little Akaki River sediment}

The concentrations of trace metals in Little Akaki River sediment samples are presented in Table 2. The ranges for concentrations of trace metals elements in the sediment samples were: $\mathrm{Zn}=78.96-235.2 \mathrm{mg} /$ $\mathrm{kg} ; \quad \mathrm{Cr}=2.19-440.8 \mathrm{mg} / \mathrm{kg} ; \quad \mathrm{Cd}=2.09-4.16 \mathrm{mg} / \mathrm{kg}$; and $\mathrm{Pb}=30.92-596.40 \mathrm{mg} / \mathrm{kg}$. The mean concentration of trace elements varied across different sampling sites, reflecting sources and amount of metal inputs. The lowest mean concentrations of $\mathrm{Zn}, \mathrm{Cr}, \mathrm{Cd}$ and
$\mathrm{Pb}$ which were recorded at sampling sites $\mathrm{S} 7, \mathrm{~S} 1, \mathrm{~S} 5$ and S3 were $78.96 \pm 0.021 \mathrm{mg} / \mathrm{L} ; 2.19 \pm 0.014 \mathrm{mg} / \mathrm{L}$, $2.09 \pm 0.001 \mathrm{mg} / \mathrm{L}$, and $30.92 \pm 0.018 \mathrm{mg} / \mathrm{L}$, respectively, indicating low anthropogenic inputs of those trace metals. The highest mean concentration of $\mathrm{Zn}$ was recorded at the sampling site (S9) which may be attributed to the use of agrochemicals, influx wastewater released from Kaliti industrial site and municipal waste treatment plant. Whereas the highest concentration of $\mathrm{Cr}$ occurred at (S3) might be due to the discharge of wastewater into the river from the nearby Addis Ababa and Dire Tanning industries. The highest concentration of $\mathrm{Cd}$ recorded at (S1) in the sediment may originate from agrochemicals (Modaihsh et al, 2004) like fertilizers which the farmers used for crop production. A high concentration of $\mathrm{Pb}$ was detected at the sample site (S4). This site is located in "Kera" below Addis Ababa City Abattoir and where irrigated vegetable cultivation is practiced. In proximity to this sample site, there are many garages, vehicle battery repair shops, and fuel filling station which discharge their wastes directly into the river without treatment (Itanna 2002). Vehicle garage wastes that may contain scrubbed solders, pigment, paints and cable covers (Melaku 2005) as well as unauthorized dumping of old batteries into the surrounding environment cloud be possible sources for accumulation of $\mathrm{Pb}$ in the sediment. In this respect, Akan et al. (2010) reported that vehicle batteries, solder, pigments, rust inhibitors, vehicle emission are important sources of lead.

To evaluate the levels of trace metal accumulation in Little Akaki River sediment, a comparison was made with that of sediment quality guidelines and world river sediment average value (Table 2). A comparison made with that of sediment quality guidelines provided by USEPA SQGs (Giesy and Hoke 1990), the concentration values of $\mathrm{Zn}$ in eight sampled sites, $\mathrm{Cr}$ and $\mathrm{Pb}$ in three sampled 
Table 2 Mean concentrations and standard deviations of trace metals in LAR sediment

\begin{tabular}{|c|c|c|c|c|}
\hline \multirow[t]{2}{*}{ Sample site code } & \multicolumn{4}{|c|}{ Mean and standard deviation of heavy metals concentrations in sediment $(\mathrm{mg} / \mathrm{kg})$} \\
\hline & Zn & $\mathrm{Cr}$ & Cd & $\mathrm{Pb}$ \\
\hline S1 & $82.24 \pm 0.013$ & $2.19 \pm 0.014$ & $4.160 \pm 0.0001$ & $37.44 \pm 0.012$ \\
\hline S2 & $150 \pm 0.001$ & $30.72 \pm 0.001$ & $4.12 \pm 0.001$ & $41.48 \pm 0.008$ \\
\hline S3 & $167.2 \pm 0.001$ & $440.80 \pm 0.003$ & $3.04 \pm 0.001$ & $30.92 \pm 0.018$ \\
\hline S4 & $159.6 \pm 0.001$ & $56.6 \pm 0.001$ & $2.92 \pm 0.001$ & $596.4 \pm 0.066$ \\
\hline S5 & $170.49 \pm 0.003$ & $52.17 \pm 0.002$ & $2.09 \pm 0.001$ & $61.15 \pm 0.041$ \\
\hline S6 & $92.84 \pm 0.024$ & $48.84 \pm 0.009$ & $2.60 \pm 0.001$ & $372.4 \pm 0.011$ \\
\hline S7 & $78.96 \pm 0.021$ & $36.6 \pm 0.008$ & $2.44 \pm 0.001$ & $31.12 \pm 0.014$ \\
\hline S8 & $228 \pm 0.001$ & $174.8 \pm 0.0001$ & $4.04 \pm 0.001$ & $46.28 \pm 0.009$ \\
\hline S9 & $235.2 \pm 0.001$ & $5.92 \pm 0.004$ & $3.0 \pm 0.001$ & $43.32 \pm 0.011$ \\
\hline S10 & $118.64 \pm 0.009$ & $246.4 \pm 0.001$ & $2.96 \pm 0.001$ & $36.24 \pm 0.011$ \\
\hline Min & 78.96 & 2.19 & 2.09 & 30.92 \\
\hline Max & 235.2 & 440.8 & 4.16 & 596.4 \\
\hline Range & $78.96-235.2$ & $2.19-440.8$ & $2.09-4.16$ & $30.92-596.40$ \\
\hline Overall Mean & 148.28 & 109.51 & 3.14 & 129.68 \\
\hline $\begin{array}{l}\text { USEPA SQGs }{ }^{\mathrm{a}} \\
\text { Non -polluted }\end{array}$ & $<90$ & $<25$ & - & $<40$ \\
\hline Moderately polluted & $90-200$ & $25-50$ & - & $40-60$ \\
\hline Heavily polluted & $>200$ & $>50$ & $>6$ & $>60$ \\
\hline World river sediment average value ${ }^{b}$ & 303 & 126 & 1.4 & 230.75 \\
\hline
\end{tabular}

a USEPA SQGs (Giesy and Hoke 1990); ${ }^{b}$ World river sediment average value adopted from (Martin and Meybeck 1979)

sites, fall in the category of moderately polluted. In all sampled sites, the concentrations of $\mathrm{Cd}$ were below the USEPA SQGs category of heavy pollution $(<6)$. The concentration of the heavy metal that exceeded the SQG standard has a potential risk for aquatic organisms (Xia et al. 2018).

A comparison made with that of the world river sediment average value indicated in Martin and Meybeck (1979) (See Table 2) revealed that concentrations of $\mathrm{Cr}$ in three sampled sites $(\mathrm{S} 3, \mathrm{~S} 8$, and $\mathrm{S} 10)$ and $\mathrm{Pb}$ at two sampled sites (S4 and S6) exceeded the world river sediment average value. This implies that the sediments at these sites were highly enriched which may be due to varying amounts of local inputs, sources and other environmental factors influencing metal concentration (Qian et al. 2015). The concentrations of Cd in the sediment at all sampling sites surpass the world river sediment average value exhibiting an elevated concentration of Cd in Little Akaki River sediment.

Table 3 Average concentration of heavy metals ( $\mathrm{mg} / \mathrm{kg}$ ) in Little Akaki River sediment and other rivers

\begin{tabular}{|c|c|c|c|c|c|}
\hline \multirow[t]{2}{*}{ Country } & \multicolumn{4}{|c|}{ Concentrations of heavy metals in Sediment } & \multirow[t]{2}{*}{ References } \\
\hline & $\mathrm{Zn}$ & $\mathrm{Cr}$ & Cd & $\mathrm{Pb}$ & \\
\hline LAR sediment, Ethiopia & 148.28 & 109.51 & 3.14 & 129.68 & Present study \\
\hline Awash River sediment, Ethiopia & 382.73 & 120.58 & 2.60 & 13.53 & Bekele et al. (2018) \\
\hline Pearl River sediment, China & 143.10 & 78.37 & 0.46 & 49.66 & Zhao et al. (2017) \\
\hline Wen-Rui Tang River sediment, China & 1362 & 193 & 17.7 & 115 & Xia et al. (2018) \\
\hline Tigris River sediment, Iraq & 502.30 & 101.2 & 0.8 & 79.80 & Saha and Hossain ( 2010) \\
\hline Euphrates River sediment, Iraq & 48 & 58.4 & 1.87 & 22.56 & Salah et al. (2012) \\
\hline Tigris River Sediment, Baghdad & 128.73 & 164.94 & 7.38 & 71.52 & Al Obaidy et al. (2014) \\
\hline Subarnarekha River sediment, India & 50.13 & - & 1.30 & 16.14 & Manoj and Padhy ( 2014) \\
\hline Mangonbangon River sediment, Philippines & 213.71 & 89.45 & - & - & Decena et al. (2018) \\
\hline Burigangan River Sediment, Bangladesh & 502.26 & 101.2 & 0.82 & 79.4 & Saha and Hossian (2011) \\
\hline
\end{tabular}


To understand the level of pollution, a comparison was also made with other studies in the country and other developing countries and presented in Table 3. The overall mean concentration for $\mathrm{Zn}$ in sediment was almost comparable to that of the concentration reported for Pearl River in China (Zhao et al.2017) and Tigris River in Iraq (Al Obaidy et al.2014). The concentration of $\mathrm{Cr}$ in Little Akaki River sediment samples is also comparable to that of Burigangan (Bangladesh) and Tigris River sediments (Saha and Hossian 2011). However, the concentrations of Cd in Little Akaki River sediment samples were slightly higher than that of Awash River sediments in Ethiopia (Bekele et al. 2018), but by far less than Wen-Rui Tang River sediment in China (Xia et al. 2018). The concentration of $\mathrm{Pb}$ in Little Akaki River sediment samples were also higher than the reported concentration values for Awash River and Wen-Rui Tang rivers, indicating that concentrations of $\mathrm{Pb}$ in sediment were influenced by anthropogenic sources. In general, the comparison made indicated that the concentrations of $\mathrm{Cd}$ and $\mathrm{Pb}$ in Little Akaki River sediments were relatively higher and require serious attention.

\section{Enrichment factor (EF)}

Enrichment factor is widely applied to quantify the abundance of metals in sediments, the levels of enrichment and to distinguish sources of metals, whether they are derived from an anthropogenic or natural source (Al Obaidy et al. 2014; Kong et al. 2018; Zhao et al. 2017).

The enrichment factor for LAR sediment is presented in Table 4. The EF for $\mathrm{Zn}$ ranged (1.16-7.09); for $\mathrm{Cr}$ (0.03-6.84), for Cd (7.13-28.77) and Pb (1.82-30.14). According to Issa and Qanba (2016) enrichment classification, $\mathrm{Zn}$ and $\mathrm{Cr}$ showed moderate $(2 \leq \mathrm{E} \mathrm{F}<5)$ to significantly enrichment $(5 \leq \mathrm{EF}<20)$ at four sampled sites (S3, S8, S10 and S9) and three sampled sites (S8, S3 and S10), respectively.

The sediment of Little Akaki River was moderately enriched with $\mathrm{Pb}$ at five sampling sites (S1, S5, S7, S8, and S10); significantly enriched at (S9) and very high $(20 \leq \mathrm{EF}<40)$ enrichment recorded at two sampling sites (S4) and (S6). In all sampled sites, Cd showed significant to very high enrichment indicating an elevated concentration of $\mathrm{Cd}$ in the sediment. The highest enrichment value for $\mathrm{Zn}, \mathrm{Cd}$ and $\mathrm{Cr}$ were detected in the lower course of Little Akaki River; $\mathrm{Zn}$ and $\mathrm{Cd}$ at the site (S9), and $\mathrm{Cr}$ at (S10). Elevated enrichment of $\mathrm{Cd}$ and $\mathrm{Zn}$ might be due to anthropogenic sources of inputs from agrochemicals, industrial wastewaters, municipal waste treatment plants, garages, and domestic wastes accumulated in and nearby river banks. Whereas $\mathrm{Cr}$ was generated from tanning industries situated in Akaki kaliti industrial areas. Painting, metal manufacturing and urban surface run-off from upstream may also contribute to the enrichment of $\mathrm{Cr}$ (Bekele et al. 2018). Agrochemicals such as phosphate fertilizer are a source of trace metals such as $\mathrm{Cr}, \mathrm{Cd}$, $\mathrm{Pb}$ and $\mathrm{Ni}$ (Modaihsh et al. 2004). The highest enrichment of these trace metals at the lower course of the river may also be attributed to clay dominated sediment texture. Clay and silt particles have an affinity towards heavy metals due to their high specific surface area (Rubio et al. 2000; Saha and Hossain 2011).

The highest EF of $\mathrm{Pb}$ that detected at the sampling site (S4) might be due to anthropogenic inputs from garages, vehicle battery maintenance shops and dumping of old batteries (Akele et al. 2016; Bentum et al. 2011; Melaku 2005).

Based on mean EF values, the decreasing order of trace metals enrichment in LAR sediment was: $\mathrm{Cd}(15.44)>\mathrm{Pb}$

Table 4 Enrichment factor and geo-accumulation index of Little Akaki River sediment

\begin{tabular}{|c|c|c|c|c|c|c|c|c|}
\hline \multirow[t]{2}{*}{ Sample Site code } & \multicolumn{4}{|c|}{ Enrichment Factor (EF) } & \multicolumn{4}{|c|}{ Geo-accumulation ( $\left.\mathrm{I}_{\text {geo }}\right)$} \\
\hline & $\mathrm{Zn}$ & $\mathrm{Cr}$ & Cd & $\mathrm{Pb}$ & $\mathrm{Zn}$ & $\mathrm{Cr}$ & Cd & $\mathrm{Pb}$ \\
\hline S1 & 1.17 & 0.03 & 18.84 & 3.93 & -0.8 & -5.94 & 3.21 & 0.93 \\
\hline S2 & 1.42 & 0.31 & 12.36 & 1.88 & 0.07 & -2.14 & 3.2 & 0.46 \\
\hline S3 & 2.05 & 5.70 & 11.84 & 1.82 & 0.23 & 1.71 & 2.75 & 0.04 \\
\hline S4 & 1.68 & 0.63 & 9.76 & 30.14 & 0.16 & -1.26 & 2.69 & 4.31 \\
\hline S5 & 1.83 & 0.80 & 7.13 & 3.15 & 0.26 & -1.37 & 2.21 & 1.03 \\
\hline S6 & 1.40 & 0.78 & 12.49 & 27.05 & -0.62 & -1.47 & 2.53 & 3.63 \\
\hline S7 & 1.16 & 0.57 & 11.39 & 2.20 & -0.86 & -1.88 & 2.44 & 0.06 \\
\hline S8 & 3.03 & 2.45 & 17.08 & 2.96 & 0.68 & 0.37 & 3.17 & 0.62 \\
\hline S9 & 7.09 & 0.19 & 28.77 & 6.27 & 0.72 & -4.51 & 2.74 & 0.53 \\
\hline S10 & 3.12 & 6.84 & 24.74 & 4.58 & -0.35 & 0.87 & 2.72 & 0.28 \\
\hline Mean & 2.40 & 1.83 & 15.44 & 8.40 & -0.05 & -1.56 & 2.77 & 1.19 \\
\hline
\end{tabular}


(8.40) $>\mathrm{Zn}$ (2.40), $\mathrm{Zn}>\mathrm{Cr}$ (1.83). Thus, anthropogenic enrichment of toxic elements especially $\mathrm{Cd}$ and $\mathrm{Pb}$ may pose an adverse effect on the aquatic environment and public health.

\section{Geo-accumulation Index $\left(\mathrm{I}_{\text {geo }}\right)$}

Table 4 shows the mean $\mathrm{I}_{\text {geo }}$ values for $\mathrm{Zn}(-0.05), \mathrm{Cr}$ (- 1.56), $\mathrm{Cd}$ (2.77), and Pb (1.19). According to Muller's (1981) scale, the computed mean $\mathrm{I}_{\text {geo }}$ values for $\mathrm{Zn}$ and Cr were found to be in class $0\left(\mathrm{I}_{\text {geo }}\right.$ value $\left.\leq 0\right)$ indicating that LAR sediments were not contaminated with these two metals. However, the $\mathrm{I}_{\text {geo }}$ value for $\mathrm{Pb}$ was found to be in class $4\left(\mathrm{I}_{\text {geo }}\right.$ value $\left.=3.63\right)$ at the sampling site $(\mathrm{S} 6)$ exhibiting that Little Akaki River sediments were strongly contaminated. More serious contamination of sediment with $\mathrm{Pb}$ that fall in class 5 recorded at sample site (S4) $\left(\mathrm{I}_{\text {geo }}=4.31\right)$ indicating strong to extreme contamination. Similarly, the $\mathrm{I}_{\text {geo }}$ values for $\mathrm{Cd}$ were found to be in class $3\left(\mathrm{I}_{\text {geo }}\right.$ value $\left.=2-3\right)$ at sampling sites $(\mathrm{S} 3, \mathrm{~S} 4, \mathrm{~S} 5, \mathrm{~S} 6, \mathrm{~S} 7$, S9 and S10) indicating that the sampled sediments were moderate to strongly contaminated. Whereas three sampled sites (S1, S2 and S8) were in class $4\left(\mathrm{I}_{\text {geo }}\right.$ value $\left.=3-4\right)$ exhibiting strong contamination of sediments in these sites. Previously, Berhanu et al. (2018) reported that the sediments of LAR catchment were moderate to strongly contaminated with $\mathrm{Cd}$. The decreasing order of geo-accumulation were: $\mathrm{Cd}(2.77)>\mathrm{Pb}(1.19)>\mathrm{Cr}(-1.56)>\mathrm{Zn}$ $(-0.05)$. Hence, both EF and $I_{\text {geo }}$ results indicated that the concentration of $\mathrm{Cd}$ in the sediment was elevated in comparison to other trace metals due to anthropogenic influence.

\section{Contamination factor (CF)}

The level of sediment contamination by trace elements is often expressed in terms of a contamination factor. The contamination factor for $\mathrm{Zn}$ ranged (0.83-2.48); Cr (0.024-4.9); Cd (6.97-13.87), and $\mathrm{Pb}$ (1.55-29.82). According to Hakanson (1980) classification of the levels of contamination factor, the computed $\mathrm{CF}$ values for $\mathrm{Zn}$ at seven sampling sites (S2, S3, S4, S5, S8, S9 and S10); Cr at two sampling sites ( $\mathrm{S} 8$ and $\mathrm{S} 10$ ) and $\mathrm{Pb}$ at seven sampling sites(S1, S2, S3, S7, S8, S9 and S10) were found to be in class 2 exhibiting moderate contamination $(1 \leq \mathrm{CF}<3)$ of sediments with these trace metals. A considerable contamination $(3 \leq \mathrm{CF}<6)$ with $\mathrm{Cr}$ was detected at the sampling point (S3). This sampling site is located in proximity to tanning industries which release untreated or poorly treated tannery wastewaters usually loaded with Cr (Mortazavi and Hatami 2018; Alemu et al. 2016; Xia et al. 2018) into the river. Similarly, a considerable sediment contamination $(3 \leq \mathrm{CF}<6)$ with $\mathrm{Pb}$ detected at sampling site $(\mathrm{S} 5)$ and very high contamination $(\mathrm{CF}>6)$ at sampling sites (S4) and (S6) (Fig. 4) mainly due to

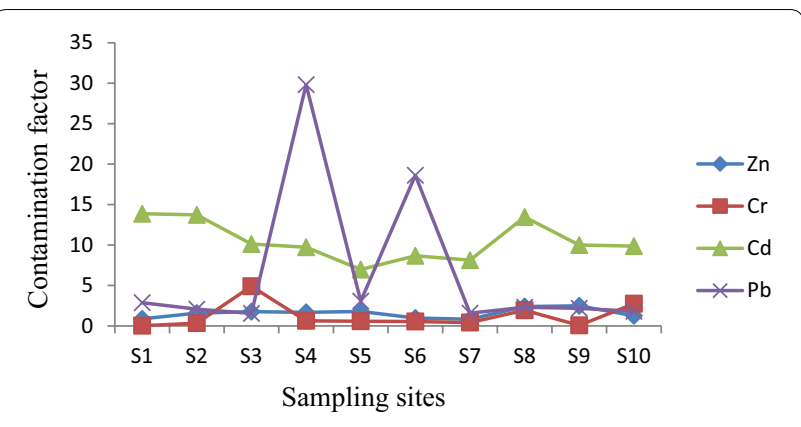

Fig. 4 CF of Little Akakai River sediment

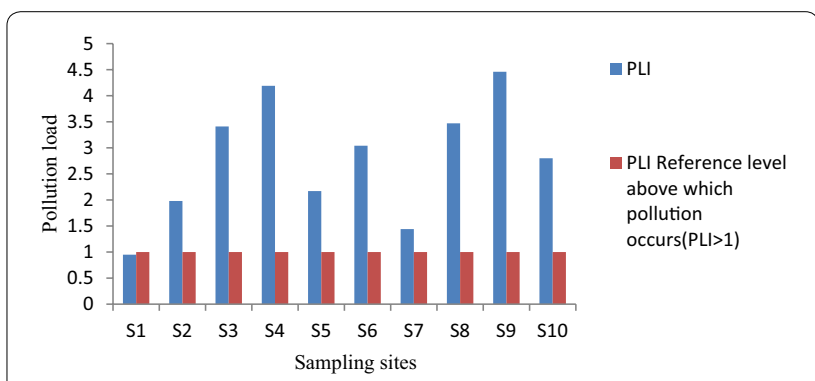

Fig. 5 Pollution load index of Little Akaki River sediments

anthropogenic inputs of $\mathrm{Pb}$ from vehicle battery maintenance shops, garages and fuel filling stations.

In all sampled sites, the $\mathrm{CF}$ values for $\mathrm{Cd}(\mathrm{CF}>6)$ found to be in (class 4$)$ exhibiting a very high $(C F>6)$ level of sediment contamination. $\mathrm{Cd}$ can be generated from multiple sources of inputs in downstream; these include electroplating, batteries, paints and pigments factories, garages, vehicles washing, domestic and municipal wastes (Mortazavi and Hatami 2018), agricultural use of phosphorus, zinc and iron fertilizers (Manoj and Padhy 2014).

In terms of mean $\mathrm{CF}$ of trace elements, the decreasing order of CF was: $\mathrm{Cd}(10.56)>\mathrm{Pb}(6.37)>\mathrm{Zn}(1.44)>\mathrm{Cr}$ (1.19). These results indicated that $\mathrm{Cd}$ and $\mathrm{Pb}$ were the main elements that largely contributed to contaminations of LAR sediment. Hence, contamination of sediment with $\mathrm{Cd}$ and $\mathrm{Pb}$ which are highly toxic can be harmful to aquatic organisms.

\section{Pollution load index (PLI)}

The PLI of Little Akaki River sediment was ranged between 0.95-4.46 with an average value of 2.79. According to Tomilson et al. (1980) interpretation of the PLI values except at sample site (S1) which is the control sample site (PLI value $<1$ exhibiting no pollution); in all other sampled sites, the sediments were contaminated (PLI $>1$ ) with heavy metals. 
The decreasing order of PLI in downstream was: (S9) $>(\mathrm{S} 4)>(\mathrm{S} 8)>(\mathrm{S} 3)>(\mathrm{S} 6)>(\mathrm{S} 10)>(\mathrm{S} 5)>(\mathrm{S} 2)>(\mathrm{S} 7)>(\mathrm{S} 1)$ (Fig. 5). This result demonstrated that the lower part of LAR, particularly the sample site (S9) was received the highest pollution load of heavy metals as compared to other sites located in the mid and upper courses of the river. Thus, the highest PLI implied high metal inputs mainly from the municipal wastewater treatment plant, Kaliti industrial site and agro-chemicals from surrounding irrigated vegetable farms. Besides, physical land scope (gentle flat land), hydrological flow (gently river flows conditions) and clay dominated particle size might have facilitated the adsorption and deposition of suspended metals. Consequently, the highest PLI value reflects that the quality of sediments at this sample site was highly deteriorated due to high anthropogenic metal inputs (Al Obaidy et al. 2014; Likuku et al. 2013; Manoj and Padhy 2014; Sekabira et al. 2010).

\section{Hierarchical Cluster Analysis (HCA)}

The cluster analysis was undertaken after standardization of the measured concentrations of heavy metals in the sediments using mean transformation as suggested in Rencher (2002). The hierarchical cluster analysis was undertaken following squared Euclidean distance as measures of similarity to group ten sample sites into three clusters (Fig. 6). Each cluster is described in terms of location, sources, concentrations of heavy metals and pollution load (Sojka et al. 2019; Zhao et al. 2012).

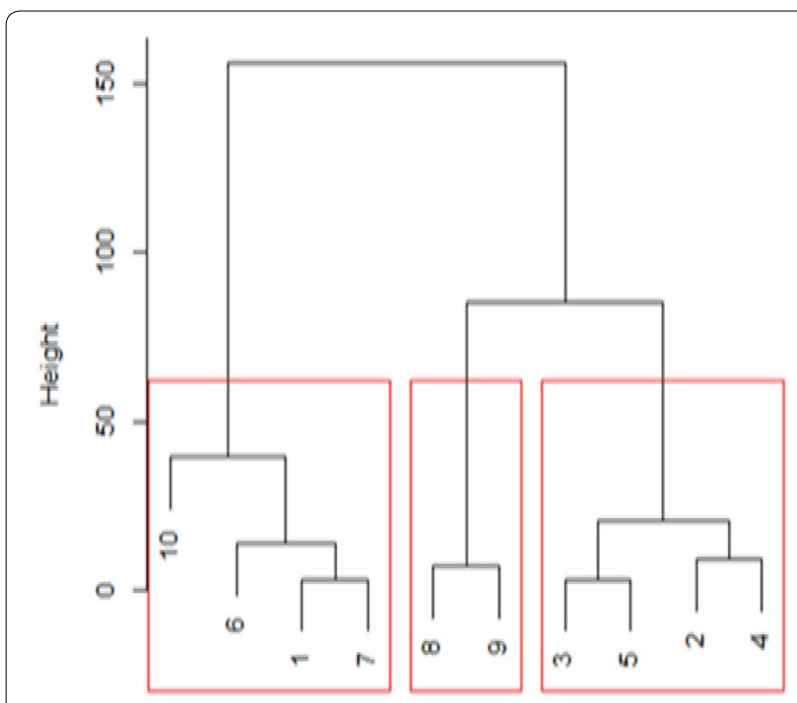

Sampling sites

Fig. 6 Hierarchical cluster analysis of Little Akaki River sediment

\section{Cluster 1}

Consists of sample sites (S10), (S6), (S1) and (S7). Sample sites (S1) and (S7) closely resembled each other as they were mainly subjected to non-point sources of metals inputs from agrochemicals as they were surrounded by crop and irrigated vegetable farms; hence they had low PLI (S1 = 0.95; S7 = 1.44). Similarly, sampling sites (S10) and (S6) also closely resembled each other even though sampling site (S10) is located in the lower end of LAR, while sampling site S6 is located in the mid-course of the river These two sampling sites received metal load from varied sources of inputs, but, they had similar PLI, S6 (3.04) and S10 (2.80); hence, they were clustered.

\section{Cluster 2}

Encompasses two sample sites: (S8) and (S9) which display similar features. Both sampling sites are located in the lower course of the river. The sampling site (S8) is located close to Kaliti industrial site where many industries are operating, whereas the sampling site (S9) is located some distance below the sample site (S8) and received influx wastes from kaliti industrial site, Addis Ababa city municipal wastewater treatment plant, quarry wastes and agrochemicals. As a result, the sampling site (S8) had high concentrations of $\mathrm{Zn}, \mathrm{Cr}$ and $\mathrm{Cd}$ while (S9) had high $\mathrm{Zn}$ and $\mathrm{Cd}$ concentrations. Thus, sampling sites (S8) and (S9) closely resembled due to their location and exposure to high pollution load from industries which can be demonstrated by high PLI of (3.47) and (4.46), respectively.

\section{Cluster 3}

Consists of sample sites (S3), (S5), (S2) and (S4). These sampling sites are found in the upper and upper-mid courses of the river. Sample site (S2) closely resembles (S4) as had comparable $\mathrm{I}_{\text {geo }}$ and CF values for $\mathrm{Zn}$ and $\mathrm{Cr}$. Similarly, the sampling site (S3) closely resembles sample site (S5) as they had comparable geo-accumulation index for $\mathrm{Zn}$ and $\mathrm{Cd}$. The CF for $\mathrm{Zn}$ at the sampling site (S3) and S5 were also comparable; hence, closely clustered. In general, cluster analysis sites with similar contamination levels and sample sites found in proximity to the industrial site were exhibiting high PLI.

\section{Correlation}

Pearson correlation analyzed at confidence limits (CL) of $95 \%$ was run to identify the association and sources of trace metals and the result was presented in Table 5.

A strong positive correlation recorded between element pairs: $\mathrm{Zn}-\mathrm{Cd}(\mathrm{r}=0.478)$ indicated that they may be originated from common sources such as industries. But low correlation observed between $\mathrm{Zn}-\mathrm{Cr}$ $(\mathrm{r}=0.260), \mathrm{Zn}-\mathrm{Pb}(\mathrm{r}=0.017)$, and $\mathrm{Cr}-\mathrm{Cd}(\mathrm{r}=0.053)$. 
Table 5 Pearson correlation of heavy metals in Little Akaki River sediments

\begin{tabular}{llllll}
\hline $\mathrm{pH}$ & 1 & & & \\
$\mathrm{Zn}$ & -0.005 & 1 & & & \\
& $(0.988)$ & & & & \\
$\mathrm{Cr}$ & -0.013 & $0.260(0.468)$ & 1 & & \\
& $(0.972)$ & & & & \\
$\mathrm{Cd}$ & -0.491 & $0.478(0.162)$ & $0.053(0.885)$ & 1 & \\
& $(0.150)$ & & & & \\
$\mathrm{Pb}$ & $0.387(0.269)$ & $0.017(0.963)$ & -0.194 & -0.133 & 1 \\
& & & $(0.592)$ & $(0.715)$ & \\
\hline
\end{tabular}

: Sig (2-tailed) presented in bracket; $(\mathrm{CL}=95 \%)$

Table 6 PERI and RI of heavy metals in Little Akaki River sediment

\begin{tabular}{|c|c|c|c|c|c|}
\hline \multirow[t]{2}{*}{ Sample site code } & \multicolumn{4}{|c|}{$\begin{array}{l}\text { The potential ecological } \\
\text { risk factor of single metal } \\
\left(\mathrm{E}_{\mathrm{r}}^{\mathrm{i}}\right)\end{array}$} & \multirow[t]{2}{*}{ RI of heavy metals } \\
\hline & $\mathrm{Zn}$ & $\mathrm{Cr}$ & $\mathrm{Cd}$ & $\mathrm{Pb}$ & \\
\hline S1 & 0.87 & 0.05 & 416 & 14.36 & 431.28 \\
\hline S2 & 1.58 & 0.68 & 412 & 10.45 & 424.71 \\
\hline S3 & 1.76 & 9.80 & 304 & 7.73 & 323.29 \\
\hline S4 & 1.68 & 1.26 & 292 & 149.10 & 444.04 \\
\hline S5 & 1.79 & 1.16 & 209 & 15.29 & 227.24 \\
\hline S6 & 0.98 & 1.09 & 260 & 93.10 & 355.17 \\
\hline S7 & 0.83 & 0.81 & 244 & 7.78 & 253.42 \\
\hline S8 & 2.40 & 3.88 & 404 & 11.57 & 421.85 \\
\hline S9 & 2.48 & 0.13 & 300 & 10.83 & 313.44 \\
\hline S10 & 1.25 & 5.48 & 296 & 9.06 & 311.79 \\
\hline Average & 1.56 & 2.43 & 313.70 & 32.93 & 350.62 \\
\hline
\end{tabular}

The absence of strong association among trace elements suggested that metals didn't have common sources as their inputs are controlled by a combination of different factors such as geo-chemicals and their mixed associations (Ren et al. 2015). Negative associations between $\mathrm{Pb}$ and $\mathrm{Cr}(\mathrm{r}=-0.194) ; \mathrm{Pb}$ and $\mathrm{Cd}(\mathrm{r}=-0.133)$ suggested that these elements deposited in sediments were not associated with each other, and they were derived from diverse and different sources (Chatterjee et al. 2007). Berhanu et al. (2018) has also reported a negative correlation between $\mathrm{Cr}-\mathrm{Cd}$, and $\mathrm{Pb}-\mathrm{Cd}$ for the sediment of the Akaki River catchment. The concentrations of $\mathrm{Zn}, \mathrm{Cr}$ and $\mathrm{Cd}$ were negatively correlated with sediment $\mathrm{pH}$, indicating that the $\mathrm{pH}$ may be the main factor affecting their distribution in LAR sediments (Ke et al. 2017).

\section{Ecological risk assessment}

The potential ecological risk index (PERI) and Risk index (RI) values of Little Akaki River sediment are presented in Table 6. According to Hakanson's (1980) classification, the PERI values for $\mathrm{Zn}, \mathrm{Cr}$ and $\mathrm{Pb}$ were categorized in class 1 exhibiting low ecological risk $\left(\mathrm{E}_{\mathrm{r}}^{\mathrm{i}}<40\right)$. However, in sample sites (S4) and (S6) the PERI values for $\mathrm{Pb}$ was found to be in class 3 indicating considerable ecological risk $\left(\mathrm{E}_{\mathrm{r}}^{\mathrm{i}}=80-160\right)$ of pollution to river water The ecological risk of $\mathrm{Cd}$ at seven sampling sites (S3, S4, S5, S6, S7, S9, and S10) found to be in class 4 indicating high ecological risk $\left(\mathrm{E}_{\mathrm{r}}^{\mathrm{i}}=160-320\right)$ while at three sampling sites (S1, S2 and S8) exhibited very high risk $\left(E_{r}^{i}>320\right)$. High risk of $C d$ is partly explained by higher geo-accumulation and high EF, and partly due to its higher toxicity response factor as compared to other elements under study (Ghaleno et al. 2015).

The cumulative risk of four trace metals (RI) ranged 227.24-444.04 with an average value of 350.62. RI values for all sampling sites were found to be in class 2 $(R I=150-300)$ and class3 (RI value $=300-600)$ exhibiting moderate to considerable risk to the river ecosystem.

A comparison made with other study reports in the country and elsewhere showed that the mean RI value (350.62) for Little Akaki River sediment is comparable to that of the Awash River Basin sediments in Ethiopia with a mean RI value (355.54) (Bekele et al. 2018). Similarly, Ke etal. (2017) have reported comparable average RI value (358.35) for Liaohe River sediment in China.

\section{Eco-toxicological effects assessment}

Threshold effect concentration (TEC), probable effect concentration (PEC) and interim sediment quality guidelines (ISQGs) were used to assess the toxicological effects of sediment pollution on aquatic life. According to Burton (2002), there are less adverse biological effects when the concentrations of metals in sediment are found below the TEC value; adverse biological effects can occasionally occur when the concentrations equal or exceed the TEC, but lower than the PEC value. However, adverse biological effects frequently occur if the concentrations of trace metals equal or exceed the PEC value (Ke et al. 2017).

As shown in Table 7, the concentrations for $\mathrm{Zn}, \mathrm{Cr}$, $\mathrm{Cd}$ and $\mathrm{Pb}$ in sediment surpassed the USEPA (TEC) and CCME (ISQGs) guidelines limit values indicating that the sediments may occasionally pose adverse biological effects on sediment dwelling organisms. Especially, the concentrations of $\mathrm{Cr}$ and $\mathrm{Pb}$ which exceeded PEC limits of (CCME), and the concentration of $\mathrm{Pb}$ that slightly surpassed the CB-PEC guideline limit of USEPA, implying that adverse effects to aquatic life frequently happen. 
Table 7 Concentrations of metals in Little Akaki River sediment (mg/kg) and SQGs values

\begin{tabular}{|c|c|c|c|c|c|}
\hline \multirow[t]{2}{*}{ Metal } & \multirow{2}{*}{$\begin{array}{l}\text { Overall mean concentration of elements } \\
\text { in LAR sediment }(\mathrm{mg} / \mathrm{kg})\end{array}$} & \multirow{2}{*}{$\begin{array}{l}\text { USEPA (2002) } \\
\text { CB-TEC }^{\mathrm{a}}(\mathrm{mg} / \mathrm{kg})\end{array}$} & \multirow[b]{2}{*}{$\begin{array}{l}\text { CB-PEC }{ }^{\mathbf{b}}(\mathrm{mg} / \\
\mathrm{kg})\end{array}$} & \multicolumn{2}{|l|}{ CCME (2001) } \\
\hline & & & & $\mathrm{ISQGs}^{\mathrm{c}}(\mathrm{mg} / \mathrm{kg})$ & $\mathrm{PEC}^{\mathrm{d}}(\mathrm{mg} / \mathrm{kg})$ \\
\hline $\mathrm{Zn}$ & 148.28 & 121 & 459 & 123 & 315 \\
\hline $\mathrm{Cr}$ & 109.51 & 43.4 & 111 & 37.3 & 90 \\
\hline $\mathrm{Pb}$ & 129.68 & 35.8 & 128 & 35.0 & 91.3 \\
\hline $\mathrm{Cd}$ & 3.14 & 0.99 & 4.98 & 0.6 & 3.5 \\
\hline
\end{tabular}

${ }^{a}$ Consensus based threshold effect concentration (CB-TEC) (USEPA 2002); ${ }^{b}$ Consensus based -probable effect concentration (CB-PEL) of (USEPA 2002); ${ }^{\mathrm{C}}$ interim Sediment Quality Guidelines (ISQGs) of (CCME 2001); d Probable effects concentration (PEC) of (CCME 2001)

The concentrations of $\mathrm{Cr}$ at sampling sites (S3, S8 and $\mathrm{S} 10)$ and $\mathrm{Pb}$ at (S4 and S6) exceeded CB- PEC and CCME ( $\mathrm{PEC}$ ) limit values. Similarly, $\mathrm{Cd}$ at sampling sites (S1, $\mathrm{S} 2$, and S8) surpassed PEC values of CCME. Thus, $\mathrm{Cr}, \mathrm{Pb}$ and $\mathrm{Cd}$ may frequently pose adverse biological impacts in these identified sample sites.

\section{Conclusions}

The study results indicated that Little Akaki River sediments were highly enriched with $\mathrm{Cd}$ and $\mathrm{Pb}$ (except for two sites) in all sampled sites The enrichment of $\mathrm{Zn}$ and $\mathrm{Cr}$ were detected in a few sample sites. The Geo-accumulation index further confirmed that the quality of sediment was severely affected by the widespread and higher accumulation of $\mathrm{Cd}$ and $\mathrm{Pb}$.

Pollution load index and hierarchical cluster analysis revealed that lower parts of the river course received the higher metal load compared to mid and upper courses due to higher metals inputs from Kalti industrial site and agrochemicals applied on irrigated vegetable farms. Pearson correlation analysis showed that $\mathrm{Zn}$ and $\mathrm{Cd}$ originated from common sources such as industries and agrochemicals.

PERI and RI values indicated that $\mathrm{Cd}$ and $\mathrm{Pb}$ were potent elements widely spread downstream and can pose a high risk of sediment contamination. Moreover, the eco-toxicological assessment results indicated that the concentrations of $\mathrm{Zn}, \mathrm{Cr}, \mathrm{Cd}$ and $\mathrm{Pb}$ in the sediments were exceeded USEPA (TEC) and CCME (ISQGs) guideline limits and may occasionally pose adverse effects on sediment dwelling aquatic life. The findings from this study clearly showed that using contaminated little Akaki river for irrigation, fishing, cattle drinking and domestic uses can have adverse public health implications. Therefore, to mitigate the river pollution with heavy metals, wastewaters from domestic and industrial sources should not be released into the river system without treatment and meeting national discharge standards. Local specific eco-smart green technologies such as phytoremediation could also be applied to purify contaminated sites to address the current problems and ensure sustainable use of resources.

\section{Abbreviations}

CB-PEL: Consensus-based probable effect concentration; CB-TEC: Consensusbased threshold effect concentration; CCME: Canadian Council of Ministers of Government; CF: Contamination factor; EF: Enrichment factor; Igeo: geoaccumulation index; ICP-OES: Inductivity coupled plasma optical emission spectrometer; ISQGS: Interim sediment quality guidelines; PLI: Pollution load index; PEC: Probable effects concentration; PERI: Potential ecological risk index RI: Risk index; SQGs: Sediment quality guidelines; SD: Standard deviation; TEC: Threshold effect concentration; TRF: Toxicity response factor.

\section{Acknowledgements}

The authors would like to acknowledge the Centre for Environmental Science, Addis Ababa University for laboratory and logistical support to undertake the study.

\section{Authors' contributions}

All the authors have made a vital intellectual contribution to realize this study. DMM has designed the study, collected and analyzed samples, interpreted the results, and wrote the draft manuscript. SLA and ABK have participated in designing the study, involved in data collection, analysis and interpretation, structuring the manuscript; and provided critical comments and suggestions on the draft manuscript. All authors read and approved the final manuscript.

Funding

The authors kindly acknowledge Addis Ababa University for financial support from its thematic research programme to undertake this study.

\section{Availability of data and materials \\ The data used in this manuscript was originated from field sediment samples collection and laboratory analysis and are available from the corresponding author upon request.}

Ethics approval and consent to participate Not applicable.

\section{Consent for publication}

Not applicable.

\section{Competing interests}

The authors declare that they have no competing interests.

\section{Publisher's Note}

Springer Nature remains neutral with regard to jurisdictional claims in published maps and institutional affiliations.

\section{Author details}

${ }^{1}$ Center for Environmental Science, Addis Ababa University, P.O. Box 1176, Addis Ababa, Ethiopia. ${ }^{2}$ Department of Chemistry, Debre Berhan University, P.O.Box 445, Debre Berhan, Ethiopia. 
Received: 22 June 2020 Accepted: 19 September 2020

Published online: 25 September 2020

\section{References}

Akan JC, Abdulrahman Fl, Sodipo OA, Ochanya AE, Askira YK (2010) Heavy metals in sediments from River Ngada, Maiduguri Metropolis, Borno State, Nigeria. J Environ Chem Ecotox 2(9):131-140

Akele ML, Kelderman P, Koning CW, Irvine K (2016) Trace metal distributions in the sediments of the Little Akaki River, Addis Ababa, Ethiopia. Environ Monit Assess 188:389

Al Obaidy AHMJ, Talib AH, Zaki SR (2014) Environmental assessment of heavy metal distribution in sediments of Tigris River within Baghdad City. Int J Adv Res 2(8):947-952

Alemu T, Lemma E, Mekonnen A, Leta S (2016) Performance of Pilot Scale Anaerobic-SBR system integrated with constructed wetlands for the treatment of tannery Wastewater. Environ Process 3(4):815-827

Burton GAJ (2002) Sediment quality criteria in use around the world. Limnology 3:65-75

Banu Z, Chowdhury MSA, Hossain MD, Nakagami K (2013) Contamination and ecological risk assessment of heavy metal in the sediment of Turag River, Bangladesh: an index analysis approach. J Water Res Prot 5:239-248

Bekele ND, Yan X, Wu H, Colebrook LL, Wang J (2018) Occurrences and ecotoxicological risk assessment of heavy metals in surface sediments from Awash River Basin, Ethiopia. Water 10:535

Bentum JK, Anang M, Boadu KO, Koranteng-Addo EJ (2011) Assessment of heavy metals pollution of sediments from Fosu Lagoon in Ghana. Bull Chem Soc Ethiop 25(2):191-196

Berhanu AK, Tarekegne BE, Jonathan OO, Seyoum LA (2018) Distribution and ecological risk assessment of trace metals in surface sediments from Akaki River Catchment and Aba Samuel Reservoir, Central Ethiopia. Environ Syst Res. https://doi.org/10.1186/s40068-018-0127-8

Canadian Council of Ministers of the Environment (CCME) (2001) Canadian sediment quality quidelines for the protection of aquatic life; summary tables, updated: in Canadian Environmental Quality Guidelines, 1999. Canadian Council of Ministers of the Environment, Winnipeg

Chatterjee M, Silva Filho EV, Sarkar SK, Sella SM, Bhattacharya A, Satpathy KK, Prasad MVR, Chakraborty S, Bhattacharya BD (2007) Distribution and possible source of trace elements in the sediment cores of a tropical macrotidal estuary and their ecotoxicological significance. Environ Int 33(3):346-356

Decena PSC, Arguelles MS, Robel LL (2018) Assessing heavy metal contamination in surface sediments in an urban river in the Philippines. Pol J Environ Stud 27(5):1983-1995

Edokpayi JN, Odiyo JO, Popoola OE, Msagati TAM (2016) Assessment of trace metals contamination of surface water and sediment: a case study of Mvudi River, South Africa. Sustainability 8:135

Gizaw M (2018) Bioaccumulation and toxicological implication of heavy metals in fish and vegetables irrigated with Akaki River, Addis Ababa, Ethiopia. MSc Thesis, Addis Ababa: Addis Ababa University.

Ghaleno OR, Sayadi MH, Rezaei MR (2015) Potential ecological risk assessment of heavy metals in sediments of water reservoir case study: Chahnimeh of Sistan. Proc Int Acad Ecol Environ Sci 5(4):89-96

Giesy JP, Hoke RA (1990) Freshwater sediment quality criteria: toxicity bioassessment. In: Baudo R, Giesy JP, Muntao M (eds) Sediment chemistry and toxicity of in-place pollutants. Lewis Publishers, Ann Arbor, p 391

Hakanson L (1980) An ecological risk index for aquatic pollution control. A Sedimentological Approach. Water Res 14:975-1001

Hu B, Cui R, Li J, Wei H, Zhao J, Bai F, Ding X (2013) Occurrence and distribution of heavy metals in surface sediments of the Changhua River Estuary and Adjacent Shelf (Hainan Island). Mar Pollut Bull 76:400-405

Issa MJ, Qanba AS (2016) Assessment of heavy metal contamination in Euphrates River Sediments from Al-Hindiya Barrage to Al-Nasiria City, South Iraq. Iraqi J Sci 57(1A):184-193

Itanna F, Anderson D, Stahr K (2003) Influence of soil type differences on the distribution of DTPA extractable heavy metals in soils irrigated with industrial effluents. Sinet Ethiop J Sci 26(1):47-54

Itanna F (2002) Metals in leafy vegetables grown in Addis Ababa and toxicological implications. Ethiop J Health Dev 16(3):295-302
Ke X, Gui S, Huang H, Zhang H, Wang C, Guo W (2017) Ecological risk assessment and source identification for heavy metals in surface sediment from the Liaohe River Protected Area, China. Chemosphere 175:473-481

Kong P, Cheng X, Sun R, Chen L (2018) The synergic characteristics of surface water pollution and sediment pollution with heavy metals in the Haihe River Basin, Northern China. Water 10:73

Li J (2014) Risk Assessment of heavy metals in surface sediments from the Yanghe River, China. Int J Environ Res Public Health 11(12):12441-12453

Likuku AS, Khumoetsile BM, Gilbert KG (2013) Assessment of heavy metal enrichment and degree of contamination around the copper-nickel mine in the Selebi Phikwe Region, Eastern Botswana. Environ Ecol Res 1(2):32-40

Luo W, Lu Y, Wang T, Hu W, Jiao W, Naile JE, Khim JS, Giesy JP (2010) Ecological risk assessment of arsenic and metals in sediments of coastal areas of northern Bohai and Yellow Seas. China. AMBIO 39(5-6):367-375

Manoj K, Padhy PK (2014) Distribution, enrichment and ecological risk assessment of six elements in bed sediments of a tropical river, Chottanagpur Plateau: a spatial and temporal appraisal. J Environ Protec 5:1419-1434

Martin J-M, Meybeck M (1979) Elemental mass-balance of material carried by major world rivers. Mar Chem 7(3):173-206

Melaku SA (2005) Investigation of input and distribution of polluting elements in Tinishu Akaki River, Ethiopia, based on the determination by ICP-MS. Dissertation, Gent: Gent University.

Modaihsh AS, Al-Swailem MS, Mahjoub MO (2004) Heavy metals content of commercial inorganic fertilizers used in the Kingdom of Saudi Arabia. Agr and Marine Sciences 9(1):21-25

Mohiuddin KM, Zakir HM, Otomo K, Sharmin S, Shikazono N (2010) Geochemical distribution of trace metal pollutants in water and sediments of downstream of an urban river. Int J Environ Sci Technol 7(1):17-28

Mortazavi S, Hatami M (2018) Assessment of ecological hazard of heavy metals $(\mathrm{Cr}, \mathrm{Zn}, \mathrm{Cu}, \mathrm{Pb})$ in surface sediments of the Bashar River, Yasouj, Iran. Arch Hyg Sci 7(1):47-60

Muller $G$ (1981) The heavy metal pollution of sediments of Neckars and its tributary. A Stocktaking Chemische Zeit. J Water Res Protec 150:157-164

Nigussie KM, Ataro AA, Bhagwan CS, Redi MA, Anton P, Robert Mc Cl (2013) Assessment of the concentration of $\mathrm{Cr}, \mathrm{Mn}$ and Fe in sediment using Laser-induced Breakdown Spectroscopy. Bull Chem Soc Ethiop 27(1):1-13

OhioEPA (2001) Sediment sampling guide and methodologies. State of Ohio Environmental Protection Agency, Lazarus Government Center, Columbus, pp 43216-51049

Özkan EY (2012) A new assessment of heavy metal contaminations in an eutrophicated Bay (Inner Izmir Bay, Turkey). Turk J Fish Aqua Sci 12:135-147

Qian Y, Zhang W, Yu L, Feng H (2015) Metal pollution in coastal sediments. Curr Pollution Rep 1:203-219

Rabee AM, Al-Fatlawy YF, Abdown Abd-Al-Husain N, Nameer M (2011) Using pollution load index (PLI) and geo-accumulation index $\left(I_{\text {geo }}\right)$ for the assessment of heavy metals pollution in Tigris River Sediment in Baghdad Region. J Al-Nahrain Univ 14(4):108-114

Ren J, Shang Z, Tao L, Wang X (2015) Multivariate analysis and heavy metals pollution evaluation in Yellow River surface sediments. Pol J Environ Stud 24(3):1041-1048

Rencher AC (2002) Methods of multivariate Analysis, 2nd edn. Brigham Young University, a John Wiley \& Sons, Inc., Publication, Canada

Rizvi N, Katyal D, Joshi V (2016) A multivariate statistical approach for water quality assessment of river Hindon, India World Academy of Science, Engineering and Technology. Int J Environ Ecol Eng 10(1):2016

Rubio B, Nombela MA, Vilas F (2000) Geochemistry of major and trace elements in sediments of the Ria de Vigo (NW Spain): an assessment of metal pollution. Mar Pollut Bull 40(11):968-980

Saha PK, Hossain MD (2011) Assessment of heavy metal contamination and sediment quality in the Buriganga River, Bangladesh, presented on the 2nd International Conference on Environmental Science and Technology IPCBEE, vol 6. IACSIT Press, Singapore

Salah EAM, Zaidan TA, Al-Rawi AS (2012) Assessment of heavy metals pollution in the sediments of Euphrates River, Iraq. J Water Res Protec 4:1009-1023

Sekabira K, Origa HO, Basamba TA, Mutumba G, Kakudidi E (2010) Assessment of heavy metal pollution in the urban stream sediments and its tributaries. Int J Environ Sci Tech 7(3):435-446 
Singovszka E, Balintova M (2016) Assessment of ecological risk of sediment in rivers of Eastern Slovakia. Chem Eng Trans 53:121-126

Sojka M, Jaskuła J, Siepak M (2019) Heavy metals in bottom sediments of reservoirs in the lowland area of Western Poland: concentrations, distribution, sources and ecological risk. Water 11(1):56

Tolla B (2006) Physico-chemical characteristics and pollution levels of trace metals in the Little Akaki and Big Akaki Rivers. M.Sc. Thesis, Addis Ababa: Addis Ababa University.

Tomilson DC, Wilson DJ, Harris CR, Jeffrey DW (1980) Problem in the assessment of heavy metals in estuaries and the formation of a pollution index. Helgol Wiss Meeresunlter 33(1-4):566-575

Turekian KK, Wedepohl KH (1961) Distribution of the elements in some major units of the Earth's Crust. Geol Soc Am Bull 72:175-192

USEPA (2001) Methods for collection, storage and manipulation of sediments for chemical and toxicological analyses: technical manual. EPA-823-B-01-002

USEPA (2002) A guidance manual to support the assessment of contaminated sediments in freshwater ecosystems. Vol-III: interpretation of the results of sediment quality investigations. EPA-905-B02-001-C

Uwah IE, Dan SF, Etiuma RA, Umoh UE (2013) Evaluation of status of heavy metals pollution of sediments in Qua-lboe River estuary and associated creeks, South-Eastern Nigeria. Environ Pollut. https://doi.org/10.5539/ ep.v2n4p110
WWAP (United Nations World Water Assessment Programme) (2017) Wastewater: the untapped resource. The United Nations World Water Development Report, UNESCO, Paris

Xia F, Qu L, Wang T, Luo L, Chen H, Dahlgren RA, Zhang M, Mei K, Huang H (2018) Distribution and source analysis of heavy metal pollutants in sediments of a rapidly developing urban river system. Chemosphere 207:218-228

Zhao Y, Xia XH, Yang ZF, Wang F (2012) Assessment of water quality in Baiyangdian Lake using multivariate statistical techniques. Procedia Environ Sci 8:1240-1253

Zhao G, Ye S, Yuan H, Ding X, Wang J (2017) Surface sediment properties and heavy metal pollution assessment in the Pearl River Estuary, China. Environ Sci Pollut Res 24:2966-2979

Zhu L, Li X, Zhang C, Duan Z (2017) Pollutants release, redistribution and remediation of black smelly river sediment based on re-suspension and deep aeration of sediment. Int J Environ Res Public Health 14:374

\section{Publisher's Note}

Springer Nature remains neutral with regard to jurisdictional claims in published maps and institutional affiliations.

\section{Submit your manuscript to a SpringerOpen ${ }^{\circ}$ journal and benefit from:}

- Convenient online submission

- Rigorous peer review

- Open access: articles freely available online

- High visibility within the field

- Retaining the copyright to your article

Submit your next manuscript at $\boldsymbol{\nabla}$ springeropen.com 